ROCZNIKI HUMANISTYCZNE

Tom LXVIII, zeszyt $10 \quad-\quad 2020$

DOI: http://dx.doi.org/10.18290/rh206810-4

ANNA MAJEWSKA-WÓJCIK

\author{
TŁUMACZENIE DYDAKTYCZNE \\ JAKO NARZĘDZIE WSPOMAGAJĄCE \\ W NAUCZANIU GRAMATYKI NIDERLANDZKIEJ \\ NA PRZYKŁADZIE IMPERATYWU
}

\title{
UWAGI WSTĘPNE
}

Lektura publikacji glottodydaktycznych, praktyka lektorska i obserwacja studentów filologii niderlandzkiej ${ }^{1}$ utwierdzają w przekonaniu, że choć przez lata poszukiwano najbardziej efektywnych i efektownych metod, thumaczenie jako narzędzie dydaktyczne $\mathrm{z}$ różnym natężeniem jest stale obecne w metodyce nauczania języków obcych. Wywodzące się z metody gramatyczno-tłumaczeniowej, długi czas nieprzychylnie postrzegane przez glottodydaktyków, odzyskało swoją wartość wraz ze zmianami w metodologii komunikacyjnej i postulowanym przez twórców Europejskiego systemu opisu kształcenia językowego (ESOKJ) podejściem ukierunkowanym na działanie, w tym działanie mediacyjne ${ }^{2}$. Nowe podejście do tłumaczenia dydaktycznego ugruntowało swe miejsce w nauczaniu języków obcych w XXI wieku. Renesans translacji pedagogicznej znajduje odbicie w ilości literatury dotyczącej różnych aspektów przekładu w dydaktyce języków obcych (np. Lipińska i Seretny; Malmkjær; Cook).

Dr Anna Majewska-WósciK - Katolicki Uniwersytet Lubelski Jana Pawła II, Instytut Językoznawstwa, Katedra Języka Polskiego; adres do korespondencji: Al. Racławickie 14, 20-950 Lublin; e-mail: amajewska@kul.lublin.pl. ORCID: https://orcid.org/0000-0002-0712-3615.

${ }^{1}$ Dziękuję dr Agnieszce Flor-Góreckiej za konsultację merytoryczną i umożliwienie mi obserwacji zajęć z gramatyki i translatoryki na studiach I stopnia filologii niderlandzkiej KUL.

${ }^{2}$ ESOKJ definiuje mediację jako: „Tłumaczenie (lub streszczenie) wypowiedzi w drugim języku obcym na pierwszy język obcy, udział w dyskusji odbywającej się w kilku językach, interpretacja zjawisk kulturowych w odniesieniu do innej kultury" (ESOKJ 151). Według Iwony Janowskiej mediacja „wymaga równocześnie uruchomienia strategii międzyjęzykowych i międzykulturowych" (Janowska 49). 
Celem niniejszego artykułu jest zwrócenie uwagi na przydatność tłumaczenia dydaktycznego $\mathrm{w}$ prezentacji oraz utrwalaniu struktury, semantyki oraz wybranych funkcji pragmatycznych form rozkaźnika ${ }^{3} \mathrm{w}$ języku niderlandzkim. Pozornie proste zagadnienie gramatyczne okazuje się nie lada wyzwaniem na poziomie pragmatyki ${ }^{4}$, zwłaszcza po uwzględnieniu kontekstu kulturowego. W tym wypadku tłumaczenie jest efektywną metodą na zapoznanie studentów zarówno z tym, co systemowe przy rozkaźniku, jak i z niuansami w zakresie użycia tej struktury gramatycznej na każdym poziomie nauki języka oraz uświadomienie niejednokrotnego braku ekwiwalencji w J1 i J2 (jeden do jednego) między formą i znaczeniem ${ }^{5}$, co w tym wypadku jest dość wyraźne.

Wnioski zostały sformułowane na podstawie obserwacji studentów polskich uczących się języka niderlandzkiego jako obcego (dalej: NVT) w ramach licencjackich studiów filologicznych KUL, wywiadu z osobą prowadzącą zajęcia $z$ gramatyki niderlandzkiej i translatoryki oraz na bazie doświadczeń autorki tekstu w nauczaniu języka polskiego jako obcego (dalej: JPjO). Studenci filologii niderlandzkiej naukę NVT rozpoczynają od podstaw. Studia licencjackie kończą ze znajomością języka na poziomie B2, $\mathrm{w}$ trakcie studiów magisterskich rozwijają kompetencje językowe na poziomie C. Na studiach I stopnia ćwiczenia z przekładu dydaktycznego stanowią komponent ćwiczeń m.in. z nauczania podsystemów języka, na studiach II stopnia dochodzi tłumaczenie specjalistyczne z J1 na J2 i odwrotnie.

Zagadnieniem trybu rozkazującego $\mathrm{w}$ języku polskim interesowali się głównie językoznawcy (m.in. Laskowski, „Semantyka”, „Peryferyjne”; Topolińska), a później pragmalingwiści ${ }^{6}$. W kontekście glottodydaktycznym dotarłam jedynie do opracowania będącego zbiorem praktycznych rozwiązań dotyczących rozkaźnika w podstawowych jego funkcjach (Kuc). W odniesieniu do imperatywu w języku niderlandzkim literatura jest uboga. Najważniejszym źródłem wiedzy jest Algemene Nederlandse Spraakkunst (E-ANS 66-67; 105-109), trudno też znaleźć opracowania glottodydaktyczne. Wydaje

\footnotetext{
${ }^{3}$ Skupiam się na thumaczeniu L1 na L2, ale oczywiście w dydaktyce języka obcego wykorzystywane jest też tłumaczenie na język ojczysty ucznia.

${ }^{4}$ To zagadnienie jest bardzo szerokie. Ograniczam się tu do zasygnalizowania problemu. Semantyka i pragmatyka imperatywu w języku polskim i niderlandzkim zostanie podjęta $\mathrm{w}$ odrębnym opracowaniu językoznawczym.

${ }^{5}$ Por. Zrób zakupy[!] = dosłownie: Doe boodschappen!, ale natywny użytkownik języka tak nie powie.

${ }^{6}$ Literatura dotycząca imperatywu jako jednego z wykładników formalnych różnych aktów mowy jest bogata i nowsza niż teksty poświęcone formom i funkcjom rozkaźnika (zob. np. bibliografia w: Gałczyńska).
} 
się, że to zagadnienie gramatyczne traktowane jest marginalnie, odwrotnie proporcjonalnie do różnorodności aspektów gramatycznych i komunikacyjnych z nim związanych.

\section{1. (NIE)ŁATWY IMPERATYW - OD FORMY DO FUNKCJI}

Formy imperatywu składają się na paradygmat fleksyjny czasownika. W codziennej komunikacji Polaków rozkaźnik pojawia się z dużą częstotliwością, jest funkcjonalny, stąd też studenci uczący się JPjO poznają jego formy już na poziomie A2 (zob. katalog gramatyczny Programy nauczania 48), natomiast studenci niderlandystyki jeszcze wcześniej, bo na poziomie A1, mimo że w niderlandzkim gramatyczny imperatyw nie jest powszechnym sposobem wyrażania modalności deontycznej. Ponieważ w tym opracowaniu rozkaźnik jest zagadnieniem egzemplifikacyjnym dla tłumaczenia dydaktycznego, wydaje się zasadne nakreślenie reguł tworzenia i stosowania trybu rozkazującego w języku polskim i niderlandzkim, czyli w języku pierwszym studentów (J1) i w języku nauczanym (J2).

\section{STRUKTURA TRYBU ROZKAZUJĄCEGO W JĘZYKU POLSKIM}

W języku polskim formy imperatywu opierają się na temacie czasu teraźniejszego czasownika - 2. lub 3. osoby Sg. dla koniugacji -e, -esz oraz e, -isz/-ysz ${ }^{7}$, np. licz-ys $\rightarrow$ licz! oraz temacie 3. osoby P1. dla koniugacji -am, -asz oraz -em, -esz, np. rozmawiaj- $\nVdash \rightarrow$ rozmawiaj!, z zerową końcówką i ewentualnymi alternacjami, np. (z)robb $\rightarrow$ (z)rób! lub z końcówką -ij/-yj (jeśli w temacie jest zbitka spółgłoskowa), np. ciagni- $\Varangle \rightarrow$ ciagnij! Część form jest nieregularna, np. być - badź!, wziać - weź!. W nauczaniu JPjO prezentację rozkaźnika rozpoczyna się od 2 . osoby $\mathrm{Sg}$. (ty), która po dodaniu końcówek -my i -cie tworzy imperatyw dla 1. i 2. os. Pl. Imperatyw w 3 os. Sg. i Pl. ma postać analityczną: partykuła niech +3 . os. Sg. i 3. osoba Pl. czasownika w trybie oznajmującym: niech on/ona/ono/pan/pani (na)pisze; niech państwo (na)pisza!. W wykładni gramatycznej pomijana jest 1. os. Sg., dla któ-

\footnotetext{
${ }^{7}$ Podręczniki do nauczania JPjO najczęściej proponują tworzenie imperatywu od tematu 2. os. Sg. Prostszą drogą, bo bazującą na temacie tej samej osoby w Sg. i Pl., byłoby budowanie rozkaźnika od tematu 3. os. Sg. i Pl., przy czym dochodzi wówczas do zatarcia przynależności czasownika do typu koniugacji.
} 
rej systemowo nie tworzy się formy imperatywnej, co nie znaczy, że nie występuje ona w języku. Funkcjonalność imperatywnego ja jest ograniczona do konkretnych kontekstów pragmatycznych. Wybrane kwestie dotyczące semantyki i funkcji rozkaźnika zostaną zasygnalizowane niżej, ponieważ wiele informacji jest uniwersalnych dla obu języków.

\section{STRUKTURA TRYBU ROZKAZUJĄCEGO W JĘZYKU NIDERLANDZKIM}

Formy rozkaźnika w języku niderlandzkim wydają się prostsze niż w języku polskim, gdyż funkcję imperatywną w obu liczbach pełni rdzeń czasownika (nie zawsze jednak tożsamy $\mathrm{z}$ rdzeniem infinitiwu). Tworzenie tej struktury pokazuje się zatem już na poziomie A1, po wprowadzeniu koniugacji ${ }^{8}$.

Tryb rozkazujący dla drugiej osoby Sg. i Pl. wykazuje synkretyzm form i jest to sam rdzeń czasownika, np. Kom hier! (Chodź!/Chodźcie tutaj!); Wacht op mij! (Poczekaj na mnie!/ Poczekajcie na mnie!).

W języku niderlandzkim w celu złagodzenia tonu wypowiedzi do form imperatywu dodaje się zaimki osobowe i/lub partykuły „łagodzące”, np. Doe de deur dicht, jullie! (Zamknijcie drzwi!); Kom eens hier, jij! (Podejdź tutaj!). Rozkaźnik bez takiej obudowy, zwłaszcza w kontaktach bezpośrednich, jest autorytarny i niegrzeczny. W celu redukcji imperatywności używa się też formuły proszącej: Wil je de deur (even) dichtdoen? (Czy chcesz (właśnie) zamknać drzwi?) lub zmiękcza ton imperatywny składnikami och, even: Och, doe even de deur dicht (E-ANS 105).

$\mathrm{W}$ formie grzecznościowej czasownik w trybie rozkazującym systemowo przyjmuje końcówkę - $t$ i występuje w prepozycji z zaimkiem $u$, np.

Gaat u zitten! (Proszę usiąść / Niech pan/pani usiądzie!/ Niech państwo usiadą!)

Doet $u$ de deur dicht! (W przybliżonym tłumaczeniu: Proszę zamknać drzwi! / Niech pan zamknie drzwi! / Niech pani zamknie drzwi! / Niech państwo zamkna drzwi!). (Wiercińska 156)

\footnotetext{
${ }^{8}$ Nie dotarłam do żadnego dokumentu odpowiadającego Programom nauczania JPjO, tzn. dokumentu obejmującego wszystkie podsystemy języka i sprawności. Kwestię nauczania poszczególnych zagadnień gramatyki NVT być może reguluje jedynie ESOKJ. Zob. też podręczniki do NVT (Bouman-Noordermeer; Van de Poel, Van Elst; Van der Toorn-Schutte).
} 
Taka forma rozkaźnika nie obsługuje jednak wszystkich sytuacji. W języku niderlandzkim, zwłaszcza w odmianie mówionej, używa się nieprzekładalnych na inne języki partykuł modalnych - operatorów trybu rozkazującego: maar, toch, eens, even, nou, spośród których eens i even łagodzą semantykę wypowiedzenia, toch i nou wzmacniają, a maar jest dwufunkcyjny (Nutilová 7).

Sprawiają one duże problemy uczącym się tego języka. Definicje słownikowe nie precyzują znaczenia tych partykuł (Van Balen, Caspers i Van der Wouden 31), możliwa więc jest różna interpretacja tego samego komunikatu, choć najczęściej zależna od kontekstu wypowiedzi, np.

Laat me die foto's [eens] zien. (Pokaż mi te zdjęcia [proszę].)

Laat me die foto's [even] zien. (Pokaż mi te zdjęcia [na chwilke].)

Laat me die foto's [maar] zien. (1. No pokaż mi te zdjęcia [bo jestem ich bardzo ciekawa].

2. No pokaż mi te zdjęcia [obejrzęje, choć w ogóle nie mam na to ochoty].)

Laat me die foto's [nou] zien. (Pokaż mi [wreszcie] te zdjęcia!)

Laat me die foto's [toch] zien. ([No] pokaż mi [w końcu] te zdjęcia!) (Wiercińska 157)

Ponieważ nie da się dokładnie wyjaśnić semantyki tych partykuł w izolacji, od użytkownika języka wymaga się określonej kompetencji językowej. Im wyższa biegłość językowa, tym częściej w języku użytkownika NVT pojawiają się partykuły modalne. Widać zatem wprost proporcjonalny związek między posługiwaniem się operatorami imperatywu a poziomem NVT, co właściwie nie dziwi, wzrasta bowiem świadomość językowa uczącego się (Van Balen, Caspers i Van der Wouden 38).

Przy imperatywie (nie tylko w języku niderlandzkim) należy pamiętać o ważnej roli intonacji, która jest sprzężona $\mathrm{z}$ semantyką i funkcją komunikatu. W tekstach pisanych do odczytania intencji nadawcy potrzebne jest osadzenie tekstu w konsytuacji komunikacyjnej.

\section{SEMANTYKA I FUNKCJE FORM IMPERATYWNYCH W JĘZYKU POLSKIM I NIDERLANDZKIM}

Zarówno w języku polskim, jak i niderlandzkim formy imperatywu wykazują duże zróżnicowanie w zakresie semantyki i pragmatyki (Laskowski, „Semantyka”; E-ANS; Duinhoven) - od łagodnej prośby do kategorycznego żądania czy groźby. Podstawową funkcją systemową rozkaźnika jest funkcja 
dyrektywna, realizowana za pomocą poszczególnych aktów mowy ${ }^{9}$, które zamykają się w ramie pragmatycznej: „Mówię, że chcę, żebyś coś zrobił...” (Komorowska 26). Werbalne oddziaływanie nadawcy na odbiorcę pełni więc funkcję nakłaniającą, zaś

Nacisk na odbiorcę może mieć na celu: $1^{\circ}$ wywołanie działania słownego (pytania) lub innego (dyrektywy: rozkazy, groźby, prośby itp.), a także: $2^{\circ}$ wpłynięcie w pewien sposób na odbiorcę, przede wszystkim na jego stan mentalny przez perswazję (rady i innego typu wypowiedzi przede wszystkim wartościujące), bądź też przez działanie manipulacyjne. (Grzegorczykowa 24)

Za pomocą języka nadawca komunikuje i oddziałuje na odbiorcę. Należy zatem za J.L. Austinem mówić o lokucji, illokucji i perlokucji (za: Komorowska 23). Imperatyw może być wykładnikiem formalnym rozkazu, nakazu, groźby, prośby, pytania, (po)rady, pocieszenia itd., czyli aktów mowy o zróżnicowanej sile illokucyjnej. Należy jednak podkreślić, że w wielu wypadkach brak jest jednoznacznego przełożenia formy na funkcję, zwłaszcza jeśli w strukturze wypowiedzenia brakuje czasownika performatywnego sygnalizującego konkretny akt mowy, dlatego też konieczne jest uwzględnienie kontekstu komunikacyjnego i intonacji (w języku mówionym). Jak słusznie zauważa Ewa Komorowska, „znajomość gramatyki danego języka winna iść $\mathrm{w}$ parze $\mathrm{z}$ wiedzą z zakresu konwencji i kultury komunikowania się (Komorowska 23-24).

Studenci uczący się NVT zapoznają się ze strukturą i funkcją rozkaźnika w sposób spiralny: na poziomie A1 poznają sposób tworzenia imperatywu w podstawowych jego funkcjach: polecenia, nakazu, zakazu. Akcent położony jest na automatyzację i utrwalenie struktury wpisanej $\mathrm{w}$ gotowy kontekst zdaniowy. Na poziomie B dochodzą kolejne funkcje: prośby, rady, ostrzeżenia, życzenia, propozycji, apelu i bardziej świadome podejście do imperatywu. Studenci dokonują zabiegów transformacyjnych - różnych operacji na strukturze zdania, pamiętając przy tym o kontekstualizacji sytuacyjnej, intencji nadawcy, elementach kulturowych czy socjolingwistycznych, podejmują zatem szeroko rozumiane działania mediacyjne. Usytuowane wśród tych działań tłumaczenie według ESOKJ ma na celu rozwijanie kompetencji komunikacyjnej (Janowska 45).

\footnotetext{
${ }^{9}$ Akt mowy jest „zamierzonym (wyrażającym intencję nadawcy) zdarzeniem komunikacyjnym" (Komorowska 23).
} 


\section{TŁUMACZENIE DYDAKTYCZNE JAKO JEDNO Z NARZĘDZI PRZY NAUCZANIU TRYBU ROZKAZUJĄCEGO NA POSZCZEGÓLNYCH ETAPACH BIEGŁOŚCI JĘZYKOWEJ}

Chociaż dydaktycy mają różne podejście do ćwiczeń tłumaczeniowych i niejednokrotnie zastanawiają się nad ich efektywnością, translacje dydaktyczne mogą przynieść wymierne efekty, jeśli są dostosowane do potrzeb grupy, stosowane celowo i celowane, czyli ukierunkowane na projektowany efekt nauczania. Na studiach filologicznych ${ }^{10}$ mamy do czynienia $\mathrm{z}$ trzema dydaktycznymi działaniami translacyjnymi, tj. z tłumaczeniem międzyjęzykowym (interlingwalnym - przekodowanie z J1 na J2 i odwrotnie), wewnątrzjęzykowym (intralingwalnym - parafrazowanie, transformacje) i thumaczeniem intersemiotycznym uwzględniającym aspekt kulturowy (Lipińska i Seretny, „Tłumaczenie w nauczaniu” 29). Wykorzystuje się również wszystkie trzy formy tłumaczenia dydaktycznego, tzn. przekład eksplikatywny (wyjaśnianie znaczeń, struktur gramatycznych i poleceń do zadań), ćwiczenia translatoryczne (utrwalanie i testowanie struktury gramatycznej) oraz test kompetencji językowych (tłumaczenie tekstów literackich i użytkowych) (Dunin-Dudkowska 101-102). Każdy z tych typów tłumaczenia może znaleźć zastosowanie przy rozkaźniku.

Właściwie na każdym etapie nauki języka przy imperatywie nauczyciel może wspomóc się tłumaczeniem eksplikatywnym i towarzyszącym mu tłumaczeniem intersemiotycznym. Na etapie początkowym celem tego typu działań może być wyjaśnienie struktury gramatycznej i pokazanie gramatycznego ekwiwalentu w J1 (w wypadku podstawowej struktury rozkaźnika jest to możliwe), zwłaszcza jeśli wyjaśnienie w J2 nie przynosi oczekiwanego efektu. Ponadto tłumaczenie może pełnić funkcję służebną przy prezentacji struktury i funkcji rozkaźnika w sposób indukcyjny. Należy też pamiętać, że naturalnym, często nieświadomym, działaniem uczącego się jest poszukiwanie odniesienia do języka ojczystego i analiza porównawcza ${ }^{11}$. Podejście bilingwalne i kontrastywne uzmysłowi studentom, na czym polegają różnice systemowe i kulturowe J1 i J2, co zwiększa szansę na wyeliminowanie błędów interferencyjnych i gaf językowych, por. Usiądź! przełożone na niderlandzki jako Zit! jest niegrzeczne. Studenci I roku niderlandystyki KUL jako natywni użytkownicy języka polskiego na co dzień posługują się formami imperatywu, ale nie zawsze są świadomi jego struktury

\footnotetext{
${ }^{10}$ Dotyczy to również kursów językowych.

${ }^{11}$ Szerzej zob. Rabiej.
} 
i niuansów w zakresie funkcjonalności, tłumaczenie dydaktyczne zatem pozwoli im nie tylko rozwijać kompetencję językową w J2 i interkulturową, ale też uświadomić system własnego języka (J1).

Nauczanie języka zakłada spiralną prezentację zagadnień, stąd też transfer eksplikatywny będzie użyteczny wówczas, gdy studenci będą się zapoznawać z operatorami trybu rozkazującego, które nie mają ekwiwalentów w języku polskim i których zastosowanie praktyczne niejednokrotnie budzi wątpliwości, zwłaszcza że dochodzi aspekt pragmalingwistyczny wypowiedzeń z imperatywem. Warto zaproponować studentom ćwiczenia translatoryczne, dzięki którym na podstawie szeregu przykładowych zdań sparowanych J1 - J2 intuicyjnie i kontekstowo wychwycą niuanse znaczeniowe do celów ćwiczeniowych można wykorzystać serię zdań utworzonych na wzór wcześniej prezentowanego wypowiedzenia: Pokaż mi te zdjęcia! Gdy w grę wchodzą znaczenia implicytne, subtelności znaczeniowe, pragmatyczne, ważna jest precyzja w oddaniu treści, a tłumaczenie na to pozwala (tłumaczenie sterowane, pod okiem nauczyciela). Dzięki temu student ma pewność, że właściwie zrozumiał komunikat w języku obcym. Zapobiegamy w ten sposób fosylizacji, czyli popełnianiu trudnych do eliminacji błędów. W tym wypadku będą to błędy pragmatyczne, rozumiane jako niedostosowanie środków językowych J2 do kontekstu sytuacyjnego i komunikacyjnego (Dąbrowska i Pasieka 112). Niewłaściwe operatory trybu „nie są przejawem jawnego złamania kodu" (Lipińska, Seretny i Turek 195), lecz znakiem niedostatecznego wyczucia językowego w J2, przez co komunikat zostaje zaburzony de facto $\mathrm{w}$ strukturze głębokiej (np. jest niezgodny $\mathrm{z}$ intencją nadawcy czy zawiera inny ladunek illokucyjny).

Ćwiczenia intra- i interlingwalne pozwalają uchwycić asymetryczność struktur i kodów. W wypadku rozkaźnika w omawianej parze językowej należy podkreślić asymetrię sprzężoną z aspektem kulturowym - to, co Polak wyrazi przy użyciu formy imperatywnej, w niderlandzkim zostanie powiedziane za pomocą innych struktur: zdania warunkowego, koniunktiwu, pytania $\mathrm{z}$ czasownikiem willen, $\mathrm{w}$ zależności od funkcji pragmatycznej trybu rozkazującego w języku polskim, np.

Niech żyje Król! - koniunktiw: Leve de Koning!

Zamknij drzwi, prosze!! - zamiast Doe de deur dicht, alsjeblieft! pytanie z willen: Wil je de deur (even) dichtdoen?

Niech cię tylko złapię na wagarach! - zdanie warunkowe: Als ik je ook maar betrap op spijbelen! 
Ważnym aspektem dydaktycznym jest odczytywanie znaczeń implicytnych. O ile większych problemów nie sprawiają wypowiedzenia $\mathrm{z}$ wpisanym w strukturę tekstu czasownikiem performatywnym, np. prosić, radzić itd. lub leksykalnym wykładnikiem wzmacniającym, np. w końcu, wreszcie, natychmiast itd., o tyle problematyczne są akty mowy o niejednoznacznej semantyce, jeśli są pozbawione płaszczyzny odniesienia. W języku mówionym sugestywna będzie intonacja, natomiast $\mathrm{w}$ języku pisanym musimy znać tło wypowiedzi, czyli ćwiczona struktura gramatyczna powinna być osadzona w rozbudowanym kontekście komunikacyjnym, np. Zostańcie $w$ domu. - może być prośbą (Zostańcie, [proszę], w domu, [tak dawno nie jedliśmy razem obiadu]), poleceniem (rodzic do dzieci: Zostańcie $w$ domu, [odróbcie lekcje]!, żądaniem/kategoryczną prośbą (Matka do dzieci: Zostańcie w domu! Nie możecie sami wychodzić!), życzeniem [Życzę wam] Zostańcie choć przez jeden dzień $w$ domu [i nacieszcie się nowym lokum], zakazem (Rodzic do dzieci: Nie wychodźcie sami! [Musicie zostać $w$ domu, dopóki nie wrócimy]. Translacja nie ogranicza się tylko do zmiany kodu językowego, ale polega również na podjęciu działań, dzięki którym przekazana będzie semantyka wraz z funkcją aktu mowy. Seryjność takich ćwiczeń translatorskich uczuli studentów na znaczenia implicytne tekstu, uwrażliwi na tło kulturowe (Majkiewicz 263) oraz docelowo pozwoli uniknąć niezręczności podczas komunikacji.

Ważnym aspektem tłumaczenia dla potrzeb dydaktyki jest możliwość dyskusji i negocjowania znaczeń (Rabiej 57), porównanie propozycji translacji $\mathrm{w}$ grupie $\mathrm{i} /$ lub zestawienie thumaczenia $\mathrm{z}$ wypowiedziami natywnych użytkowników języka, dzięki czemu rozwijamy podejście refleksyjne. Często ta sama struktura zostaje przetłumaczona w różny sposób, nawet przez native speakerów. Taka sytuacja prowokuje do analizy konfrontatywnej. Jako przykład posłuży mi różne tłumaczenie struktury imperatywnej niesystemowej w języku polskim, tj. imperatywu dla 1 os. Sg. (,ja”). Formy te są nacechowane funkcjonalnie i stąd trudne w dydaktyce, np.

Niech się w końcu wyśpię. (1. Moge ik eindelijk/uiteindelijk uitslapen. Dat ik eindelijk/uiteindelijk mag uitslapen. / 2. Ik moet nu eindelijk eens uitslapen. $)^{12}$

Niech skonam, to ty?! (1. Ik mag doodvallen als jij dat bent. / 2. 't Is niet waar, ben jij dat?)

Poczekaj, niech się ubiorę. (Wacht even totdat ik me heb omgekleed. / 2. Wacht even, ik moet me eerst aankleden.)

\footnotetext{
${ }^{12}$ Różne struktury podali mi natywni użytkownicy języka niderlandzkiego, znający też doskonale język polski: profesor filologii i tłumacz.
} 
Dzięki niejednorodności translacji studenci wypracowują dyskursywne i świadome podejście do struktur i do języka.

$\mathrm{Na}$ wyższym poziomie znajomości języka tłumaczenie dydaktyczne unaoczni problemy wynikające z uwikłania struktury w tekst, a tekstu w gatunek i kod pozajęzykowy (instrukcje, reklama itd.). Takie działania staną się pomostem pomiędzy zajęciami z praktycznej nauki języka a ćwiczeniami z przekładu specjalistycznego. Przy imperatywie na poziomie średnio zaawansowanym ćwiczenia translacyjne unaocznią też studentom wagę dodatkowych determinant socjolingwistycznych, np. układ nadawczo-odbiorczy równorzędny/nierównorzędny czy nacechowanie stylistyczne, np. daj klucz - dawaj klucz! (Geef de sleutel! - Geef maar de sleutel $\rightarrow$ Geef je me nu die sleutel [of moet ik nog lang wachten]). W tym przykładzie dochodzi jeszcze jedna kluczowa asymetria - morfologiczna: brak aspektu w języku niderlandzkim.

Ćwiczenia tłumaczeniowe sprawdzają się również jako ćwiczenia podsumowujące i sprawdzające. Moim zdaniem są narzędziem niezbędnym na każdym etapie pracy $\mathrm{z}$ subtelnościami znaczeniowo-funkcjonalnymi trybu rozkazującego. Jak pokazują badania z zakresu glottodydaktyki polonistycznej, tego typu działania wspomagają nie tylko nauczanie gramatyki, ale są też pomocne w nauczaniu wszystkich podsystemów języka i sprawności językowych (Dunin-Dudkowska; Przechodzka). To dotyczy nie tylko języków polskiego i niderlandzkiego, ale również innych języków obcych.

\section{UWAGI KOŃCOWE}

Osoby po studiach licencjackich powinny mieć wypracowaną kompetencję kontrastywno-komparatywnego podejścia do języków, powinny wychwytywać różnice systemowe między językami, a także umieć w sposób refleksyjny analizować struktury językowe i osadzać je w kontekście kulturowym. Narzędziem wspomagającym są sterowane ćwiczenia translatoryczne. Tłumaczenie dydaktyczne ma stać się pomostem prowadzącym do tłumaczenia specjalistycznego, które kształcone jest na studiach magisterskich. Jak pisze Iwona Janowska, ,tłumaczenie to jedno z bardziej autentycznych i pożytecznych działań, jakie proponuje się w ramach lekcji języka obcego" (Janowska 37) i warto z niego korzystać. Warto również przygotowywać adresowane do danej grupy ćwiczenia translatoryczne ukierunkowane na omawiany $\mathrm{w}$ danym momencie problem, ćwiczenia celowane w zależności od potrzeb i pro- 
blemów dydaktycznych. Nie chodzi w tym wszystkim, żeby studentów od razu rzucić na głęboką wodę z tłumaczeniem tekstu, a raczej o płynne przeprowadzenie z płaszczyzny mikro, czyli z poziomu słowa, poprzez strukturę gramatyczną do poziomu makro, czyli tekstów. Może to być działanie motywujące i efektywne, jeśli - zgodnie z zasadami podejścia komunikacyjnego i mediacji - położymy nacisk na dyskusję i refleksję (Janowska 38) i o ile nauczyciel będzie właściwie sterować procesem nauczania $\mathrm{z}$ wykorzystaniem thumaczenia dydaktycznego.

\section{BIBLIOGRAFIA}

Bouman-Noordermeer, Dina. Beter Nederlands Grammaticaal hulpboek voor anderstaligen Een inleiding. Uitgeverij Coutinho, 2008.

Cook, Guy. Translation in Language Teaching. Oxford UP, 2010.

Dąbrowska, Anna, i Małgorzata Pasieka. „Błędy językowe w tekstach pisanych przez cudzoziemców - wybrane problemy z klasyfikacją i oceną". Rozwijanie i testowanie biegłości w języku polskim jako obcym, red. Anna Seretny i Ewa Lipińska, Universitas, 2008, ss. 103-113.

Duinhoven, Antonius Maria „Ban de bom! Over vorm en betekenis van de imperatief”. De Nieuwe Taalgids, vol. 77, 1984, ss. 148-156.

Dunin-Dudkowska, Anna. „Thumaczenie profesjonalne i dydaktyczne a glottodydaktyka”. Ttumaczenie dydaktyczne w nowoczesnym ksztatceniu językowym, red. Anna Seretny i Ewa Lipińska, Księgarnia Akademicka, 2016, ss. 95-112.

E-ANS - Electronic Version of Algemene Nederlandse Spraakkunst. http://ans.ruhosting.nl/ e-ans/index.html

ESOKJ - Europejski systemu opisu ksztatcenia językowego: uczenie się, nauczanie, ocenianie. CODN, 2003.

Gałczyńska, Alicja. Od oswajania świata do jego wspóttworzenia. Wydawnictwo Uniwersytetu Jana Kochanowskiego, 2014.

Grzegorczykowa, Renata. „Problem funkcji języka i tekstu w świetle teorii aktów mowy”. Język a Kultura, vol. 4, 1991, ss. 11-28.

Janowska, Iwona. „Od metody gramatyczno-tłumaczeniowej do mediacji językowej. Tłumaczenie w dydaktyce języków obcych". Ttumaczenie dydaktyczne w nowoczesnym kształceniu językowym, red. Anna Seretny i Ewa Lipińska, Księgarnia Akademicka, 2016, ss. 37-53.

Komorowska, Ewa. Pragmatyka dyrektywnych aktów mowy w języku polskim. PRINT GROUP, 2008.

Kuc, Maria. „Tryb rozkazujący w różnych sytuacjach komunikacyjnych - propozycje prezentacji na lektoratach języka polskiego jako obcego (jpjo)". Kwartalnik Polonicum, vol. 22, 2016, ss. 7-18.

Laskowski, Roman. „Semantyka trybu rozkazującego”. Polonica, vol. 19, 1998, ss. 5-29. 
Laskowski, Roman. „Peryferyjne funkcje polskiego imperatywu”. Anabasis. Prace ofiarowane Profesor Krystynie Pisarkowej, red. Ireneusz Bobrowski, Wydawnictwo Lexis, 2003, ss. 153-158.

Lipińska, Ewa, i Anna, Seretny, redaktorki. Ttumaczenie dydaktyczne w nowoczesnym kształceniu językowym. Księgarnia Akademicka, 2016.

Lipińska, Ewa, i Anna, Seretny. „Tłumaczenie w nauczaniu/uczeniu się języka obcego - od słowa do tekstu". Ttumaczenie dydaktyczne w nowoczesnym ksztatceniu językowym, red. Ewa Lipińska i Anna Seretny, Księgarnia Akademicka, 2016, ss. 21-35.

Lipińska, Ewa, Anna Seretny i Przemysław Turek. „Błędy pragmatyczne uczących się języka polskiego jako obcego". Ttumaczenie dydaktyczne w nowoczesnym kształceniu językowym, red. Ewa Lipińska i Anna Seretny, Księgarnia Akademicka, 2016, ss. 181-198.

Majkiewicz, Anna. „Wybrane zagadnienia przekładu i ich użyteczność w glottodydaktyce”. Sztuka czy rzemiosło? Nauczyć Polski i polskiego, t. 1, red. Jolanta Tambor i Aleksandra Achtelik, Gnome, 2007, ss. 254-263.

Malmkjær, Kristen. „Language learning and translation”. Handbook of Translation Studies, vol. 1, ed. Yves Gambier and Luc van Doorslaer, John Benjamins Publishing Company, 2010, ss. 185-191.

Nutilová, Anna. Maar, wel, toch ,eens, even, nou. De uitdrukking van de Nederlandse modale partikels in het Tsjechisch. Masarykova Univerzita, 2012 [praca magisterska https://is. muni.cz/th/unjie/Magisterska_prace_finalni_verze.pdf].

Programy nauczania języka polskiego jako obcego. Poziomy A1-C2, red. Iwona Janowska, Ewa Lipińska, Agnieszka Rabiej, Anna Seretny i Przemysław Turek, Księgarnia Akademicka, 2011.

Przechodzka, Grażyna. „Ćwiczenia translacyjne jako jedna z technik wspomagających nauczanie języka polskiego jako obcego". Opisywanie, rozwijanie i testowanie znajomości języka polskiego jako obcego, red. Anna Seretny, Waldemar Martyniuk i Ewa Lipińska, Universitas, 2004, ss. 53-61.

Rabiej, Agnieszka. „Znalezione w przekładzie: rola języka pierwszego w nauczaniu języka obcego/drugiego". Ttumaczenie dydaktyczne w nowoczesnym ksztatceniu językowym, red. Ewa Lipińska i Anna Seretny, Księgarnia Akademicka, 2016, ss. 55-75.

Topolińska, Zuzanna. „O kategoriach gramatycznych polskiego imperativu”. Język Polski, vol. 3, 1966, ss. 67-173.

Van Balen, Erna, Johanneke Caspers, i Ton van der Wouden. „Modale partikels in het Nederlands als tweede taal: aanwijzingen voor een vaste verwervingsvolgorde". $d b \ln$, www. dbnl.org/ tekst/_nee005201001_01/_nee005201001_01_0012.php. Dostęp 25.09.2020.

Van de Poel, Kris, Sven Van Elst, i Sabine Steemans. Jo Verhoeven en Ginny De Vos. De finesses van het Nederlands. Oefenboek voor anderstaligen. Inititatief Nederlands. Acco Leuven, 1996.

Van der Toorn-Schutte, Jenny. Klare taal! Uitgebreide basisgrammatica NT2 Leer- en oefenboek Inclusief antwoorden. Boom, 1999.

Wiercińska, Katarzyna. Niderlandzki. Gramatyka z ćwiczeniami. EDGARD JĘZYKI OBCE.PL, 2016. 


\section{TŁUMACZENIE DYDAKTYCZNE JAKO NARZĘDZIE WSPOMAGAJĄCE W NAUCZANIU GRAMATYKI NIDERLANDZKIEJ NA PRZYKŁADZIE IMPERATYWU}

\section{Streszczenie}

Celem artykułu jest pokazanie korzyści płynących z tłumaczenia dydaktycznego jako wspomagającego proces dydaktyczny przy prezentacji i utrwalaniu dość prostych formalnie, ale kłopotliwych ze względu na zróżnicowanie pragmatyczne i różnice kulturowe form imperatywu w językach polskim i niderlandzkim. Translacja dydaktyczna wypowiedzeń z rozkaźnikiem ma uświadomić studentom nieprzystawalność struktury w J1 i J2, zwrócić uwagę na rozkaźnik i jego funkcje w obu językach oraz uwrażliwić na charakter grzecznościowy języka niderlandzkiego, który „nie lubi” imperatywu i zastępuje te formy łagodniejszymi strukturami, m.in. koniunktiwem, trybem warunkowym czy strukturą z czasownikiem willen. Celowane thumaczenie dydaktyczne rozwija u studentów umiejętność mediacji, pozwala uchronić przed złamaniem kodu grzeczności językowej w J2 oraz wyposaża w narzędzia translatorskie przed zajęciami z tłumaczenia specjalistycznego.

Słowa kluczowe: tłumaczenie dydaktyczne; imperatyw; język niderlandzki.

\section{TEACHING TRANSLATION AS A SUPPORTING TOOL \\ IN DUTCH GRAMMAR INSTRUCTION AS SEEN ON THE EXAMPLE OF IMPERATIVE}

\section{S u m m ary}

The aim of the article is to show the benefits of didactic translation as supporting the didactic process in introducing and revising imperative forms in Polish and Dutch, which are formally quite simple, but troublesome due to pragmatic and cultural differences. The didactic translation of commands is to make students aware of the incompatibility of the structure in L1 and L2, pay attention to the command and its functions in both languages, and recognize the politeness of the Dutch language, which "does not like" imperative and replaces these forms with softer structures, including conjunction, conditional mood or structure with the verb willen. Purposeful didactic translation develops students' mediation skills, helps protect against breaking the politeness code in L2, and equips them with translation tools before specialized translation classes.

Key words: didactic translation; imperative; Dutch. 